\title{
Assessment of Postharvest Handling Practices of Rice by Farmers across the Producing Area of Kwara State
}

\author{
M. B. Aremu", S. O. Okunade, I. A. Kurah, N. F. Okparavero, M. O. Rahman, K. C. Achime \\ Nigerian Stored Products Research Institute, KM 3, Asa Dam Road, Ilorin, Kwara State, Nigeria.
}

How to cite this paper: M. B. Aremu, S. O. Okunade, I. A. Kurah, N. F. Okparavero, M. O. Rahman, K. C. Achime. (2022) Assessment of Postharvest Handling Practices of Rice by Farmers across the Producing Area of Kwara State. International Journal of Food Science and Agriculture, 6(1), 24-34.

DOI: 10.26855/ijfsa.2022.03.005

Received: November 18, 2021

Accepted: December 20, 2021

Published: January 20, 2022

*Corresponding author: M. B. Aremu, Nigerian Stored Products Research Institute, KM 3, Asa Dam Road, Ilorin, Kwara State, Nigeria.

Email: mariambukola036@yahoo.com

\begin{abstract}
Use of available storage facility by rice farmers and marketers is considered to be low; therefore assessing the postharvest handling of rice by farmer in the study area is important. The age range of $15-20$ years old farmer have the highest participation in rice production, with $33.6 \%$; most of the respondents (43.8\%) have tertiary educational qualification, $42.1 \%$ of the respondents have the least experience of 5 to 10 years in rice farming, and rice farmers (45.1\%) in the study area cultivate between 1 and 10 hectares of rice farm. $42.3 \%$ of the respondents harvest $11-20$ bags per hectares and $15.4 \%$ of the respondents harvest up to $21-30$ bags per hectares. $91.9 \%$ of the respondents store their paddy rice after harvest while $8.1 \%$ of the respondents do not store. Majority of the respondent uses local crib (44.2\%) and warehouse/store (41.7\%) for storage. The result indicates that $5.8 \%$ respondents have their storage structure located on the farm while $49.2 \%$ have theirs in the house. 55\% of the respondent store for short period of time, (1-3 months) while $10 \%$ store for 6 months and above. $74 \%$ of the respondents are aware of latest technology to store paddy rice while $26 \%$ are not aware. $72.5 \%$ respondents are using only the controlled environment technologies in storing their paddy rice and $13.5 \%$ are using silo. Most of the respondents (73.2\%) are aware of Extension Agents (EA) and ADPs while 26.8\% are not and in the same vain $77.8 \%$ of the respondent have been visited by EA/ADP staff while $22.2 \%$ respondents have not been visited. The result shows that $77.7 \%$ respondent reported that rodents are the cause of loss of their stored paddy rice, while $10.7 \%$ respondents said it is insects.73\% of the respondents carry out pre storage operation (drying) while $19.1 \%$ do fumigate. Therefore the results indicate that the majority of rice farmers in the study area are youth however, they are not aware of the modern post harvest management practices therefore could not stored for a long period of time.
\end{abstract}

\section{Keywords}

Rice, postharvest, Respondent, Farmers, Storage facilities, Awareness

\section{Introduction}

Rice (Oryza sativa) is the third-most consumed staple food in Nigeria (after maize and cassava) and has become a food security crop due to its increased significance in the country [1]. It is an essential cash crop for small-scale farmers who commonly sold $80 \%$ of total production and consume only $20 \%$. Rice generates more income for Nigerian farmers than any other cash crop in the country [2]. 
Rice is cultivated in all Nigeria's agro-ecological zones, from the mangrove swamps of the Niger Delta to the dry zones of the Sahel in the Northern part of the Country. However, the North West accounts for $72 \%$ of total rice production in the Country [3]. A total land area of 3.2 million hectares was harvested by 1.43 million farmers in the 2018/2019 season. The two types of rice mainly cultivated in Nigeria are the African Rice (Oryza glaberrima) and the Asian rice (Oryza sativa). In recent times however, new hybrid varieties have been introduced such as NERICA [4].

There is a growing market for rice in Nigeria. This is as a result of a population increase to about 200 million people (estimated) and an average annual growth projection of $2.6 \%$ over the last 10 years. With rapid population growth expected to exceed 200 million by 2020, it is expected that the demand for rice will be sustained and increased in the foreseeable future.

Rice crop loss mainly occurs through: disease and pest by bacteria, rodents and birds; quality degradation arising from immature rice; inappropriate drying; and threshing, drying, sorting, storage, parboiling, milling and transportation. Quality control of un-husked and un-milled rice also presents additional problems to post-harvest processing.

Post-harvest handling and processing of rice consists mainly of manual operations in harvesting, threshing, drying, cleaning, parboiling, milling and packaging with attendant contamination and high crop losses [5]. Use of available storage capacity by rice farmers and marketers is considered to be low. This in turn lowers marketing efficiency by imposing constraints on volume of rice transactions. The quality of produce is also compromised by pests and rodents due to poor storage infrastructure. It is against this background this research into assessment of post harvest handling practises of rice by farmers in the producing areas of Kwara State was embarked upon

\section{Materials and Methods}

\subsection{Study Area}

The survey was conducted in Kwara State which consists of three geopolitical zones, (i.e., Kwara Central, Kwara South and Kwara North). Of all the zones, Kwara North is known for the production of various agricultural produce such as rice, maize, yam, cassava among others. Kwara North consists of Edu, Kaima, Baruten, Patigi and Moro LGAs. Among this five Local Government Areas, Edu and Patigi are the highest rice producing local government.

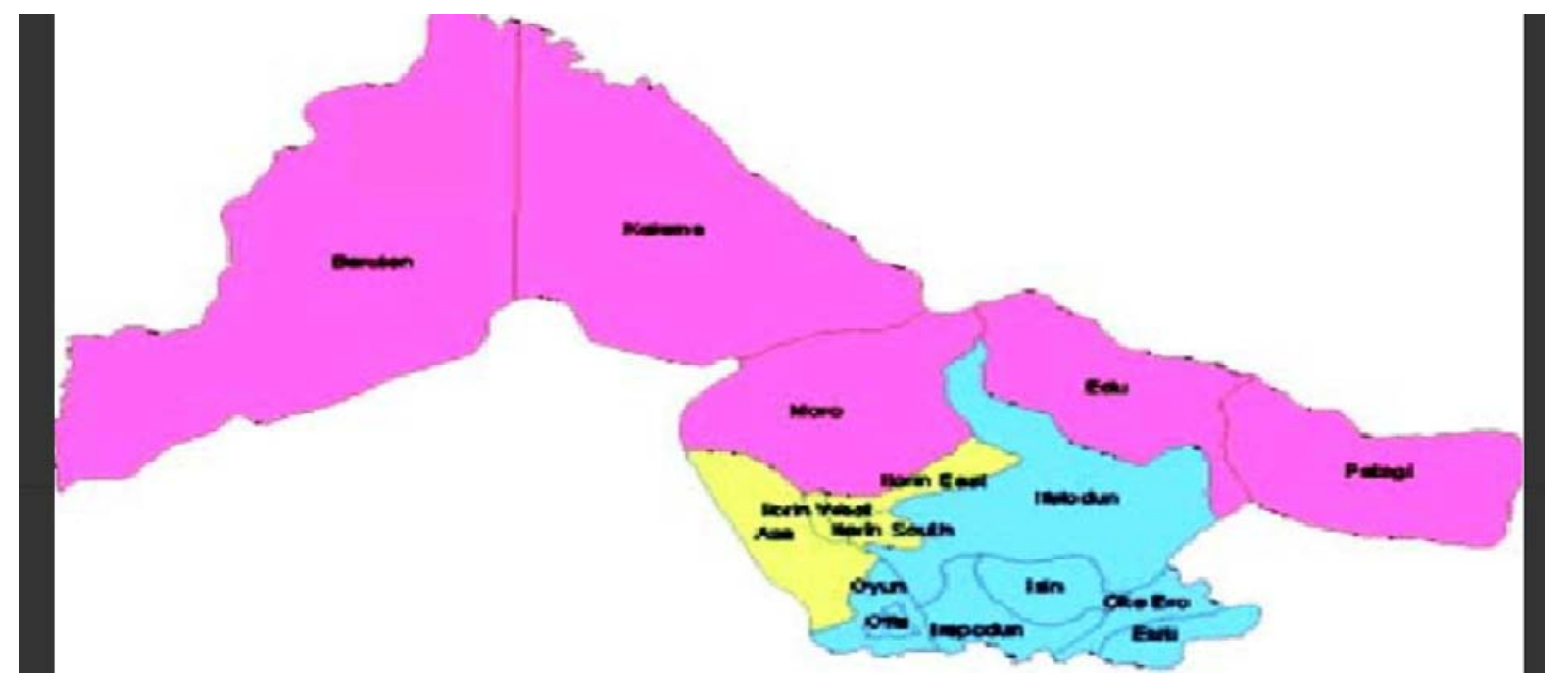

Figure 1. Map of Kwara State showing the 16 Local Government Areas and the purple zone is the Study area/High rice producing zone.

A structured questionnaire made up of 34 questions was administered to a total of one hundred and twenty five (125) rice farmers spread across Lafiagi, Bacita, Tsaragi in Edu LGA and Patigi In Patigi LGA of Kwara state. The administration of the questionnaire was done around November 2019 with the assistance of some secondary school teachers and school administrators. For ease of administration, the questions were mostly multiple choices in nature. After the interview, the data were inputted into Microsoft Excel sheet and analyzed statistically using SPSS statistical package by finding the frequency of each response and expressed as percentage of the entire respondents.

\section{Results and Discussion}

The results indicate that the majority of rice farmers in the study area are not aware of the modern post harvest management practice. The technologies some of them embark on are the old practice. The results shows that respondents are 
between the age of 15-20 years have the highest of participation with 33.6\% compared to respondents between the age group of 46 and above with 6.6\% (Figure 2) which is the lowest. The percentage decrease as the age increases; this might be as a result of strenuous activities involved in rice production process. The result is in variance with the findings of Afolami et al. [6] who reported that the mean age of the rice farmers as 48 years, and the results of Abdulhamid aand Solagberun ([7] whose respondents had a mean age of 43.5 years). In the same vein, the result is in contrary to the findings of Matanmi et al. [8] who reported that $87 \%$ of the respondents fall between $41-50$ years age category. This may be due to the year of research as youth are now fully involved in agricultural practices, possibly in response to the increasing awareness of agriculture as the way out of economic hardship, increase in price of the foreign/imported rice which has made local farmers step up production or possibly due to increase in unemployment that has forced people (including the youth) to take up agriculture (especially rice farming) as source of income

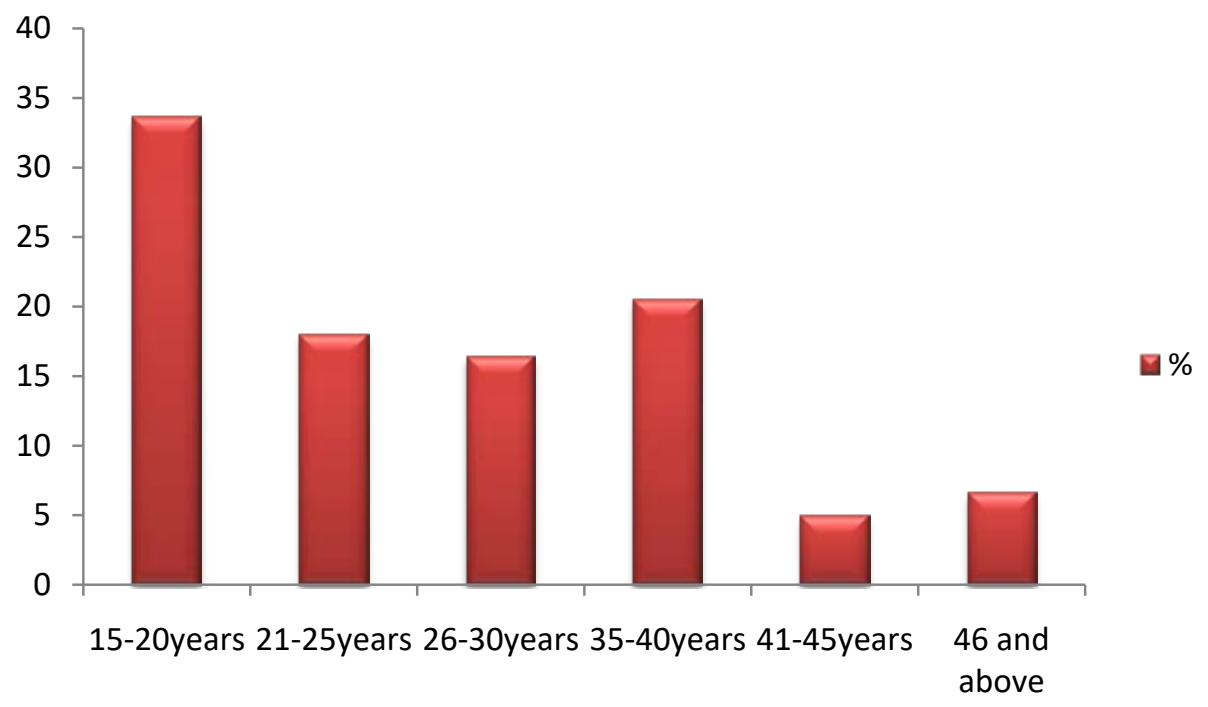

Figure 2. Frequency distribution of Rice Farmers by age groups.

The result also indicates that most of the respondents have tertiary educational qualification (43.8\%) while only few have primary education (4.1\%) and some level of illiteracy (10.7\%). This shows that youth are now going into agriculture as awareness and sensitization increases (Figure 3). The result is in contrary to earlier findings of Matanmi et al. [8] who reported that $32 \%$ of the farmer in the study area had no formal education. The results is in contrary to the report of Afolami et al. [6] that $38.9 \%$ of rice farmers had primary education, $27.4 \%$ had secondary education, while $25.1 \%$ had no education. This research no doubt shows that agriculture (especially rice production) is gaining grounds among the educated youth.

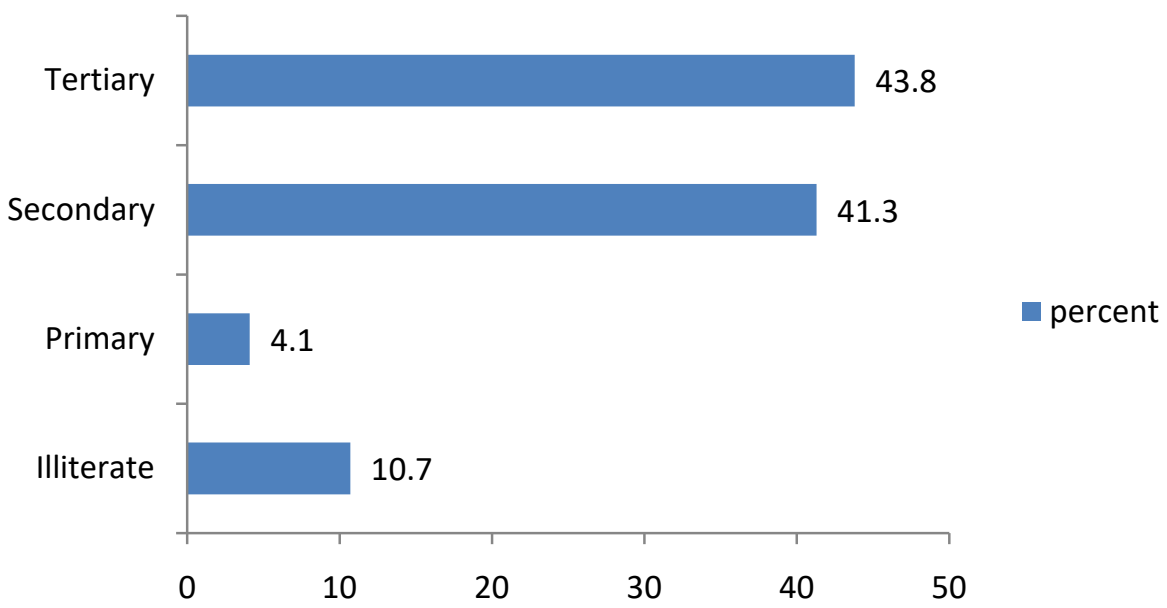

Figure 3. Educational Qualification of Rice Farmers in the Study Area. 
The study shows that $42.1 \%$ of the respondents have the least experience of 5 to10 years in rice farming possibly because most of them are youth while just 1.7\% has 36-40 years of farming experience. The results is in agreement with that of Amponsah et al. [9] who reported that only about $27 \%$ of the farmers had 20 years and above experience in rice production, with the majority of them having less than 20 years of experience in rice production. Most of the group with the higher percentage falls under youth age (Table 1). The results are in agreement with that of Abdulhamid and Solagberun [7] whose $44.3 \%$ of the respondent had more than 20 years of farming experience.

Table 1. Years of Experience in Farming in the Study Area

\begin{tabular}{|c|c|c|c|c|c|}
\hline \multicolumn{6}{|c|}{ Years of experience in farming } \\
\hline & & Frequency & Percent & Valid Percent & Cumulative Percent \\
\hline & $5-10$ & 51 & 41.5 & 42.1 & 42.1 \\
\hline \multirow{6}{*}{ Valid } & $10-15$ & 30 & 24.4 & 24.8 & 66.9 \\
\hline & $16-20$ & 13 & 10.6 & 10.7 & 77.7 \\
\hline & 21-25 & 10 & 8.1 & 8.3 & 86.0 \\
\hline & 26-30 & 10 & 8.1 & 8.3 & 94.2 \\
\hline & 31-35 & 5 & 4.1 & 4.1 & 98.3 \\
\hline & $36-40$ & 2 & 1.6 & 1.7 & 100.0 \\
\hline \multirow{3}{*}{ Missing } & Total & 121 & 98.4 & 100.0 & \\
\hline & System & 2 & 1.6 & & \\
\hline & & 123 & 100.0 & & \\
\hline
\end{tabular}

The results shows that most of the rice farmers in the study area cultivate between 1 and 10 hectares rice farm with $45.1 \%$ respondents cultivating $1-5$ hectares and only $2.5 \%$ of the respondents cultivate $16-20$ hectares of farm land (Figure 4). The results is in agreement with the reports of Afolami et al. [6] that observed that the average farm size cultivated was $1.72 \mathrm{ha}$ and $1.64 \mathrm{ha}$ for cooperative and non-cooperative members respectively. The result is also in line with that of Ayanwale and Amusan [10] who reports that most farmers (66.1\%) allocated not less than 3 hectares of land to rice cultivation. This is also an indication that youth are majorly the rice farmers with little or no support from government or any agency but were doing it for self sustenance and therefore could not go into commercial production of the crop.

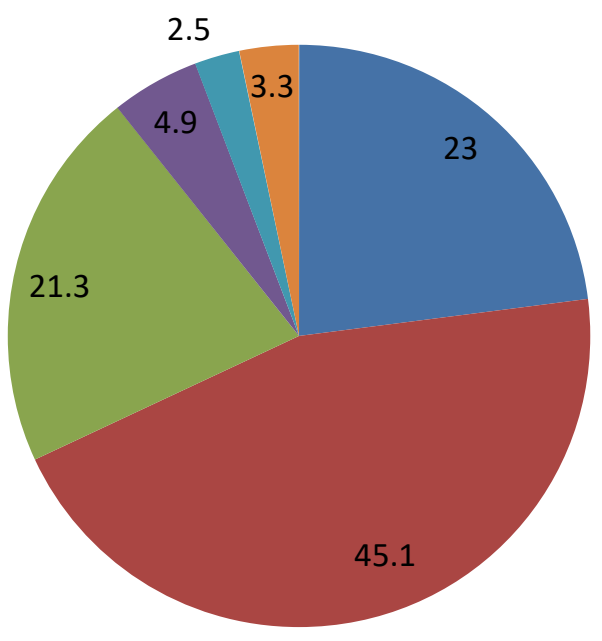

less than 1 hectare

1-5hectares

6-10hectares

11-15hectares

16-20hectares

21 and above

Figure 4. Hecterage of rice Farm cultivated by Rice Farmers in the study area.

The study indicates that $42.3 \%$ of the respondents harvest $11-20$ bags per hectares and $15.4 \%$ of the respondents harvest up to 21-30 bags per hectares. This is an indication that the expected tonnes (30bag and above) of rice is not harvested by the majority of the respondent (Figure 5). This may be due to poor knowledge of modern agronomic prac- 
tices, unwillingness to adopt change to new methods of farming, fear of making excesses arising from increase in production among others. The results is in contrary to the results of Ben-Chendo et al. [11] whose report reveals that 3.2 tonnes (62bags of $50 \mathrm{~kg}$ ) of paddy rice/hectare is recorded by farmer in the study area.

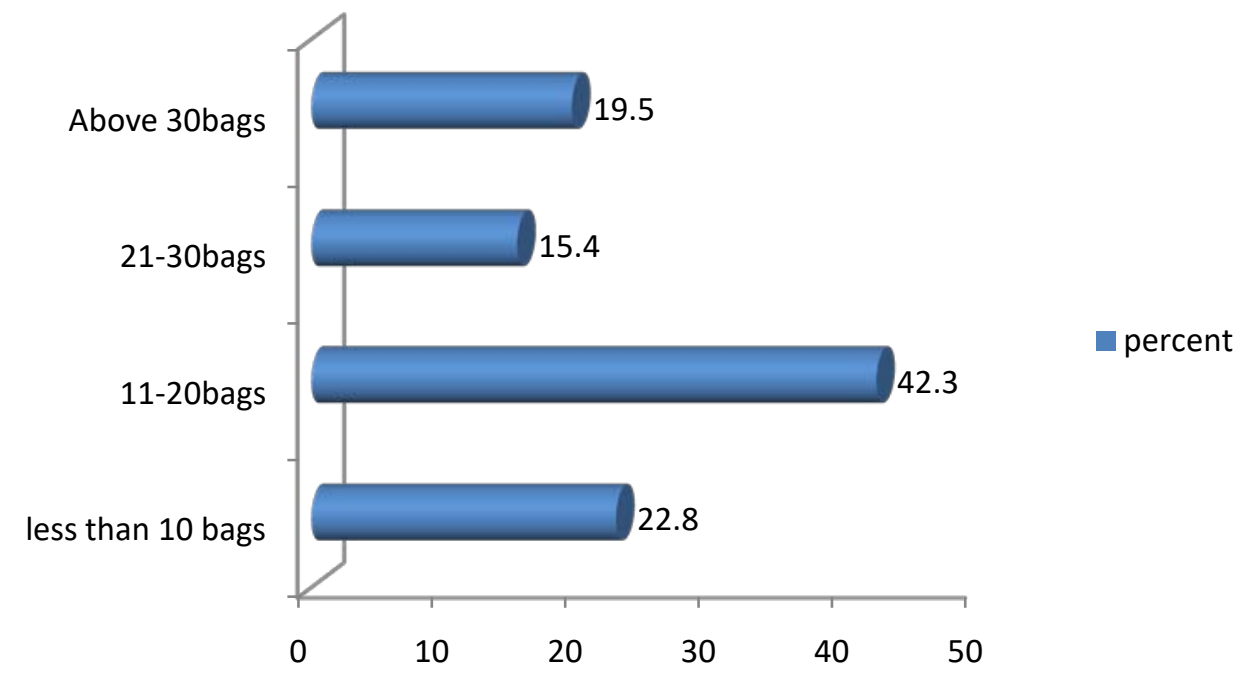

Figure 5. Average quantity of harvested rice per/hectare.

The result shows that $91.9 \%$ of the respondents store their paddy rice after harvest while $8.1 \%$ of the respondents do not store (Table 2). This indicates that most of the rice farmers know the importance of food storage (rice).

Table 2. Paddy Storage

\begin{tabular}{cccccc}
\hline & & \multicolumn{2}{c}{ Paddy Rice Storage by Respondents } & & \\
& & Frequency & Percent & Valid Percent & Cumulative Percent \\
\hline \multirow{3}{*}{ Valid } & No & 10 & 8.1 & 8.1 & 8.1 \\
& Yes & 113 & 91.9 & 91.9 & 100.0 \\
& Total & 123 & 100.0 & 100.0 & \\
\hline
\end{tabular}

Majority of the respondent uses local crib (44.2\%) and warehouse/store (41.7\%) for storage (Figure 6) which is significantly different from the percentage respondent that uses air tight storage (2.5\%).

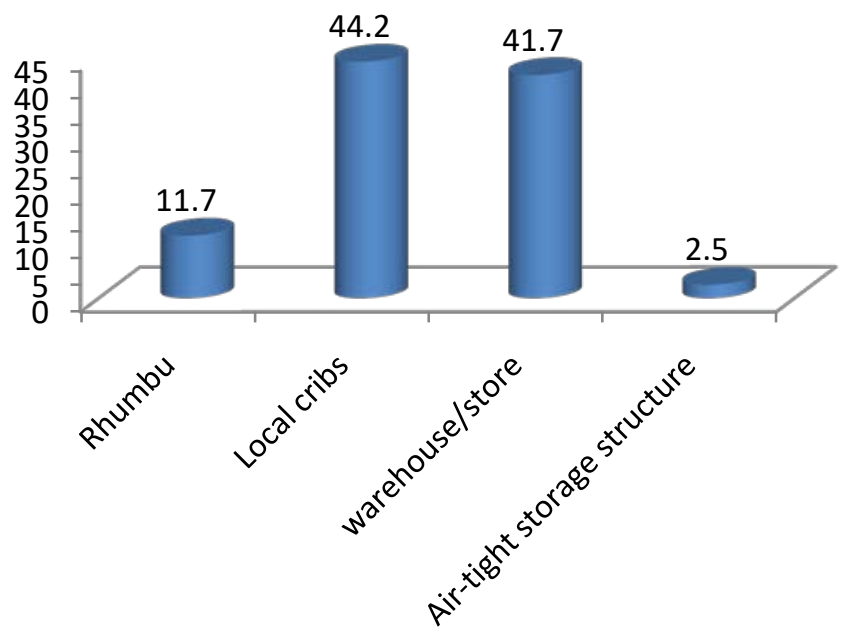

percent

Figure 6. Storage Structure Used. 
The result indicates that 5.8\% respondents have their storage structure located on the farm while $49.2 \%$ have theirs in the house (Figure 7). The results is in agreement with earlier findings of Erenstein et al. [12] whose report reveal that storage is principally in the compound (in the house or home). The results is in agreement with the earlier findings of Adejumo and Raji [13]whose result shows that the common grain storage structures existing in this zone are the mud rhombus, thatched rhombus, underground pit, and earthen pot and warehouse storage. Ashok et al. [14] reported that in India, 60-70 per cent of food grain produced is stored at home level in indigenous storage structures. Natural contamination of food grains is greatly influenced by environmental factors such as type of storage structure, temperature, $\mathrm{pH}$, moisture, etc.

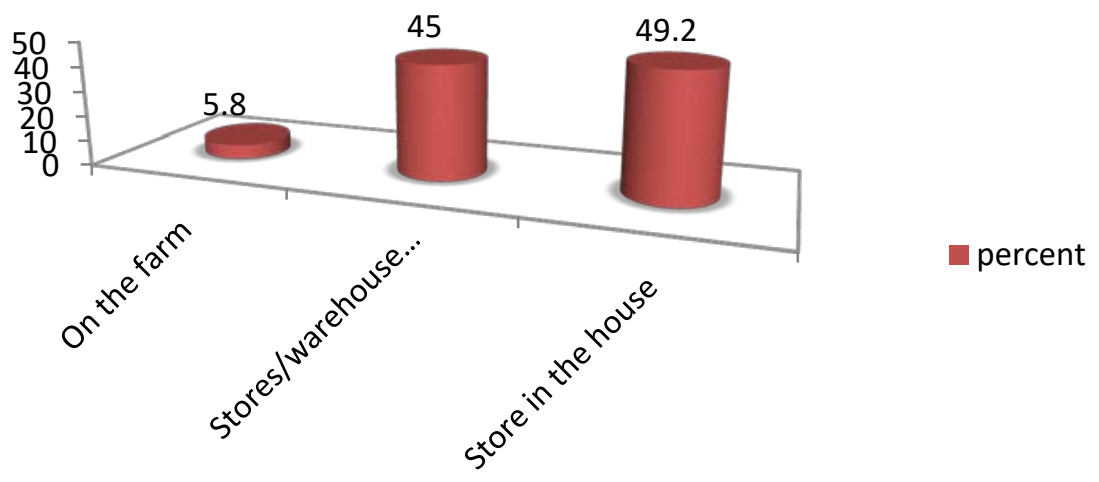

Figure 7. Location of store.

The result also indicate that 55\% of the respondent store for short period of time, that is $1-3$ months while $10 \%$ store for 6 months and above (Figure 8). This is an indication that because of the immediate need and level of poverty, farmers cannot store their harvested produce for a very long period of time to attract market value. The results in agreement with earlier findings of Erenstein et al. [12] whose reports reveal 84\% of the storage produced is for consumption at average of 5 months.

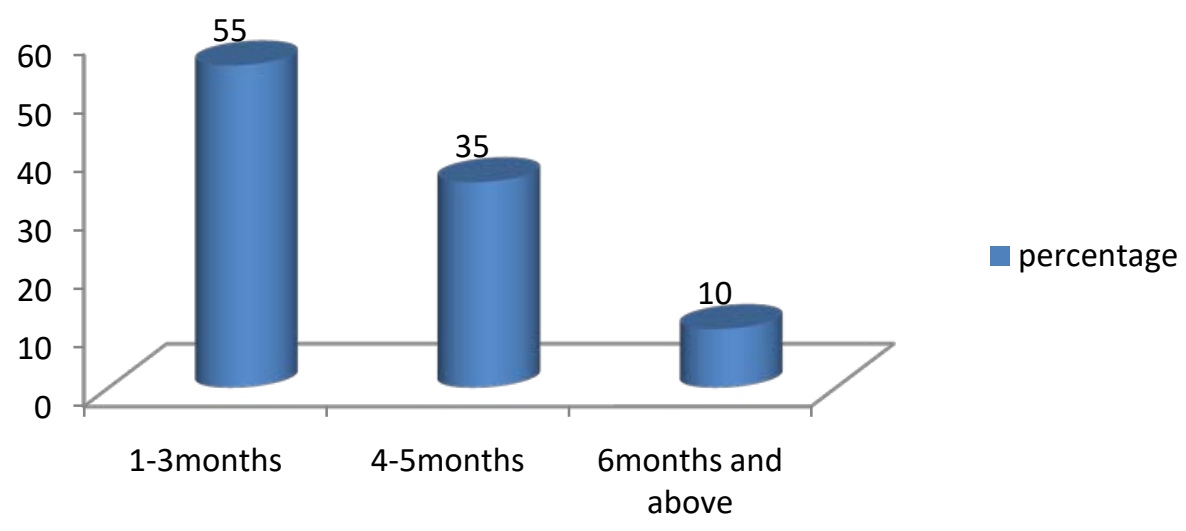

Figure 8. Length of storage of paddy rice.

Table 3 signifies that $74 \%$ of the respondents are aware of latest technology to store paddy rice while $26 \%$ are not aware.

Table 3. Awareness of Latest Technology of Paddy Rice Storage

\begin{tabular}{cccccc}
\hline & & Frequency & Percent & Valid Percent & Cumulative Percent \\
\hline \multirow{3}{*}{ Valid } & No & 32 & 26.0 & 26.0 & 26.0 \\
& Yes & 91 & 74.0 & 74.0 & 100.0 \\
& Total & 123 & 100.0 & 100.0 & \\
\hline
\end{tabular}


Information about the number of rice farmers that are aware of 1 or 2 technologies with $27.5 \%$ of the respondent acknowledge that they know up to 3 latest technology in storing paddy rice while $2.2 \%$ of the respondents knows about 5 (Figure 9).

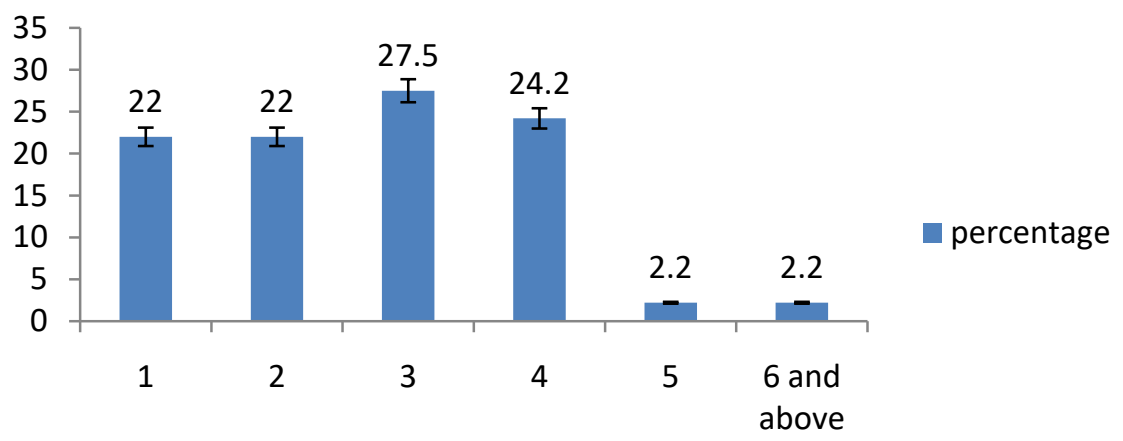

Figure 9. Number technology known by rice farmers.

When some of the storage technologies were listed, $72.5 \%$ respondents are using only the controlled environment technologies in storing their paddy rice and $13.5 \%$ are using silo. However the use of inert atmosphere is very low probably as a result of low awareness (Figure 10).

\section{Technologies known by farmers}

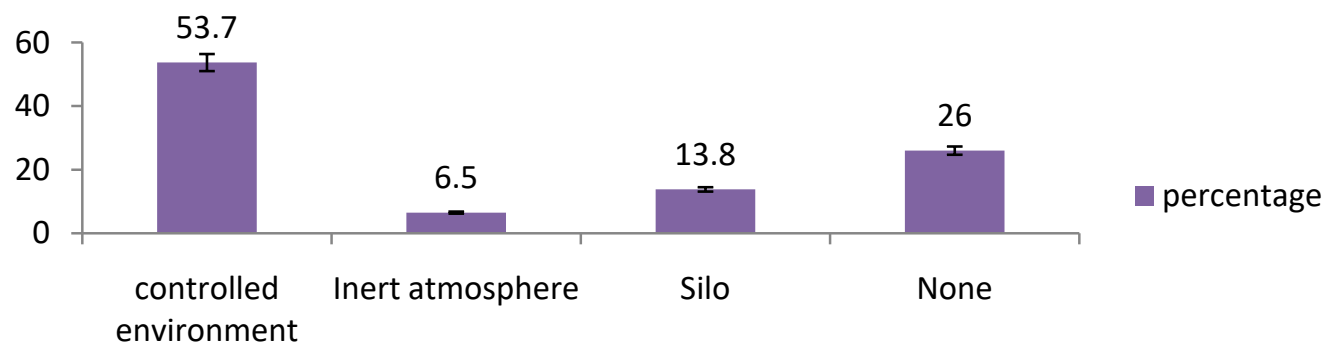

Figure 10. Types of technology known by rice farmers.

The result indicates that $73.2 \%$ of the respondents are aware of Extension Agents (EA) and ADPs while $26.8 \%$ are not aware of them and in the same vain $77.8 \%$ of the respondent have been visited by EA/ADP staff while $22.2 \%$ respondents have not been visited (Figure 11). The result in agreement with earlier findings of Orifah et al. [15] who reports that most of the respondents (86.8\%) had extension agents contacts but the prominent information sources were radio. The results is also in agreement with the findings of Abdulhamid and Solagberun [7] whose about 99.1\% of the farmers were aware of the existence of extension agents in their area.

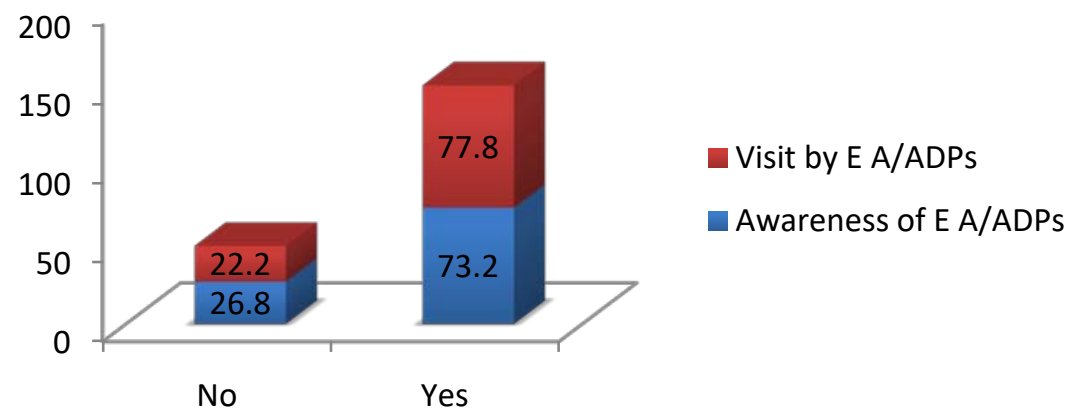

Figure 11. Awareness and Visitation of Extension agents/ADPs for Information Dissemination. 
The result also shows that $30.1 \%$ are visited by the EA/ADPs once in a year, while $43.1 \%$ of the respondents have never been visited at all (Figure 12). The results are in variance with the reports of Abdulhamid and Solagberun [7] whose $87.7 \%$ of the respondents were visited fortnightly. According to Abdulhamid and Solagberun [7], the criticism of agricultural extension services by FAO (2004) is due to its top-down approach, which has been supply-driven, technically weak, catering only for large farmers (progressive farmers) and providing insufficient coverage of the small-scale farmers, who are the producers of the bulk of food crops in Nigeria.

\section{How Often does EA/ADPs Visit}

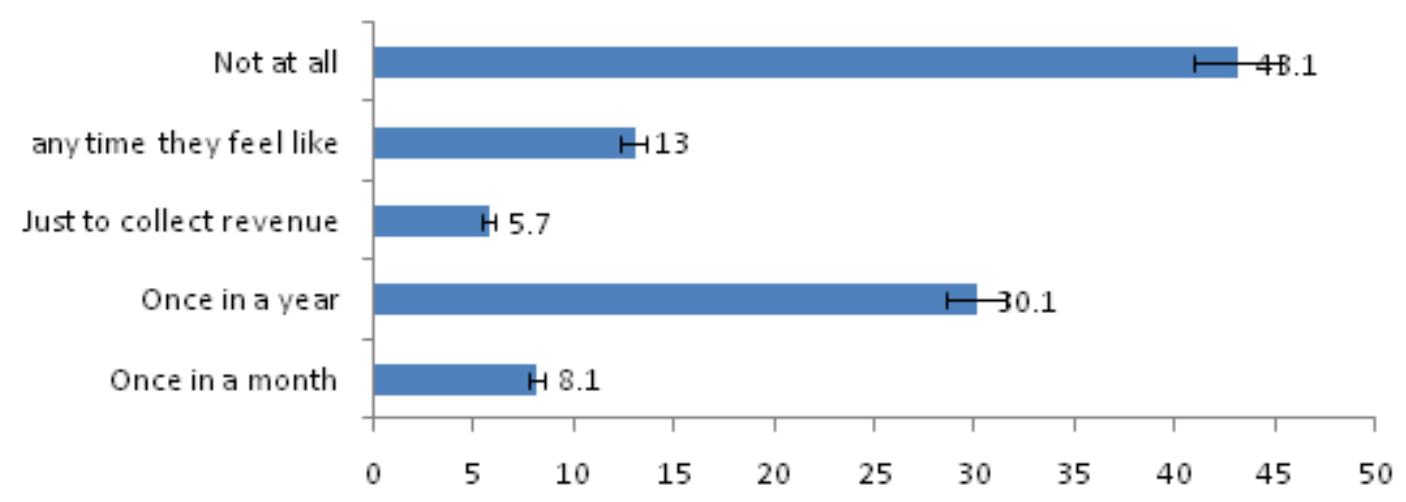

Figure 12. How often do EA/ADPs visit the Rice Farms.

Table 4 indicates $91.1 \%$ of the respondents are aware of the pest and diseases of paddy rice while $8.9 \%$ are not aware.

Table 4. Awareness of Pest and Diseases of Stored Paddy Rice

\begin{tabular}{cccccc}
\hline & & Frequency & Percent & Valid Percent & Cumulative Percent \\
\hline \multirow{3}{*}{ Valid } & No & 11 & 8.9 & 8.9 & 8.9 \\
& Yes & 112 & 91.1 & 91.1 & 100.0 \\
& Total & 123 & 100.0 & 100.0 & \\
\hline
\end{tabular}

The result shows that $77.7 \%$ of the respondent reported that rodents are the cause of loss of their stored paddy rice, while $10.7 \%$ respondents said it is insects (Figure 13).

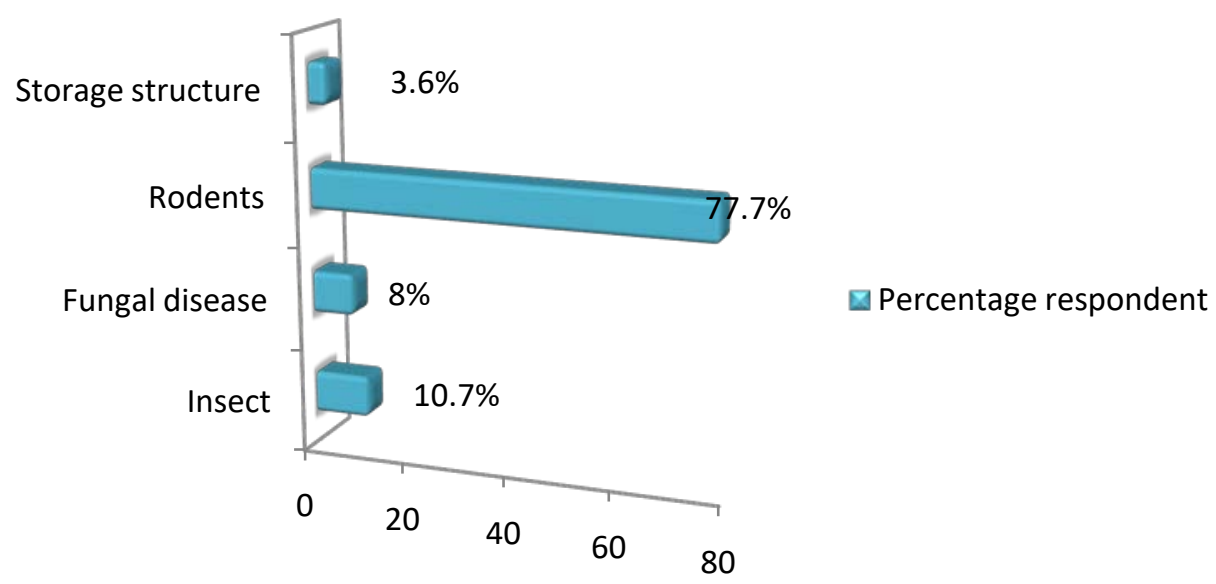

Figure 13. Causes of loss in storage.

A total of $73 \%$ of the respondents carry out pre-storage operation (drying) their harvested paddy rice before storing while $19.1 \%$ do fumigate; $4.3 \%$ sort and 3.5\% engaged in some other operations (Figure 14). 


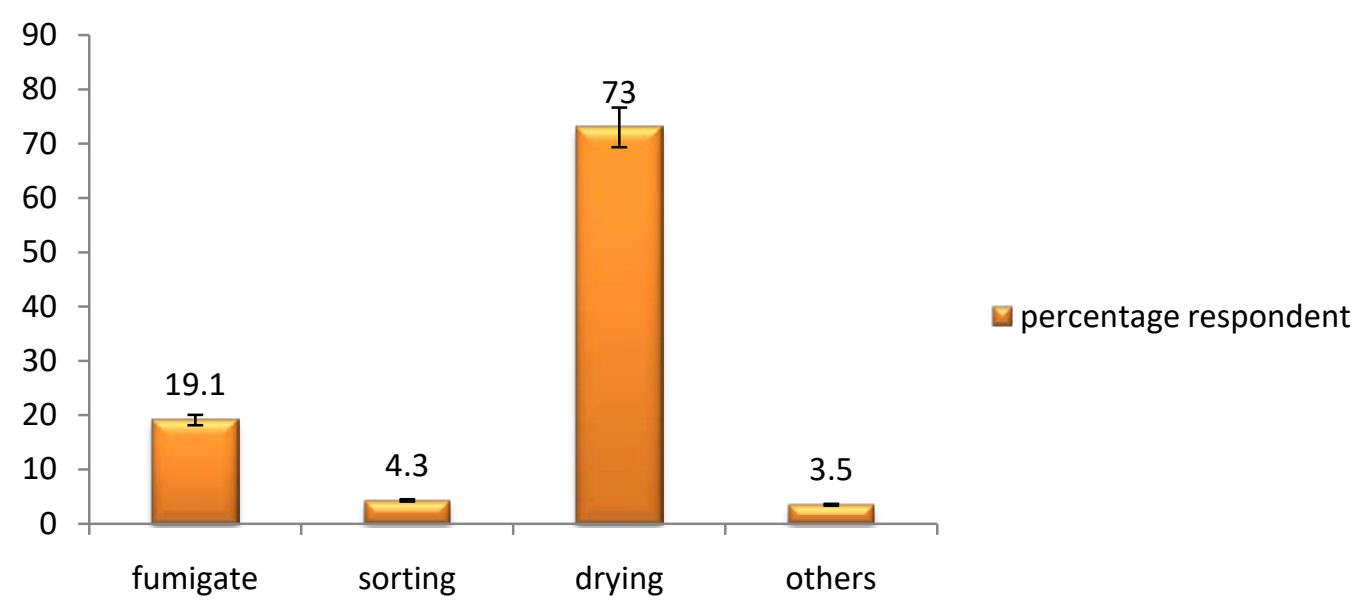

Figure 14. Pre-storage operation engaged by farmers.

The result state that inspection of stored paddy rice are done by $95.1 \%$ of the respondents while $4.9 \%$ respondent does not inspect (Table 5).

Table 5. Inspection of Stored During Storage

\begin{tabular}{cccccc}
\hline & & Frequency & Percent & Valid Percent & Cumulative Percent \\
\hline \multirow{3}{*}{ Valid } & No & 6 & 4.9 & 4.9 & 4.9 \\
& Yes & 117 & 95.1 & 95.1 & 100.0 \\
& Total & 123 & 100.0 & 100.0 & \\
\hline
\end{tabular}

Most of the respondent either inspect their store fortnightly or weekly (28.8\%) or inspect their stored paddy rice monthly (40.7\%) while $0.8 \%$ of respondents do not inspect at all (Figure 15). However, the long-recommended practice is to check your grain weekly during the summer while in winter, you will get a bit of a break-you only need to check it every few weeks as reported by Scott [16].

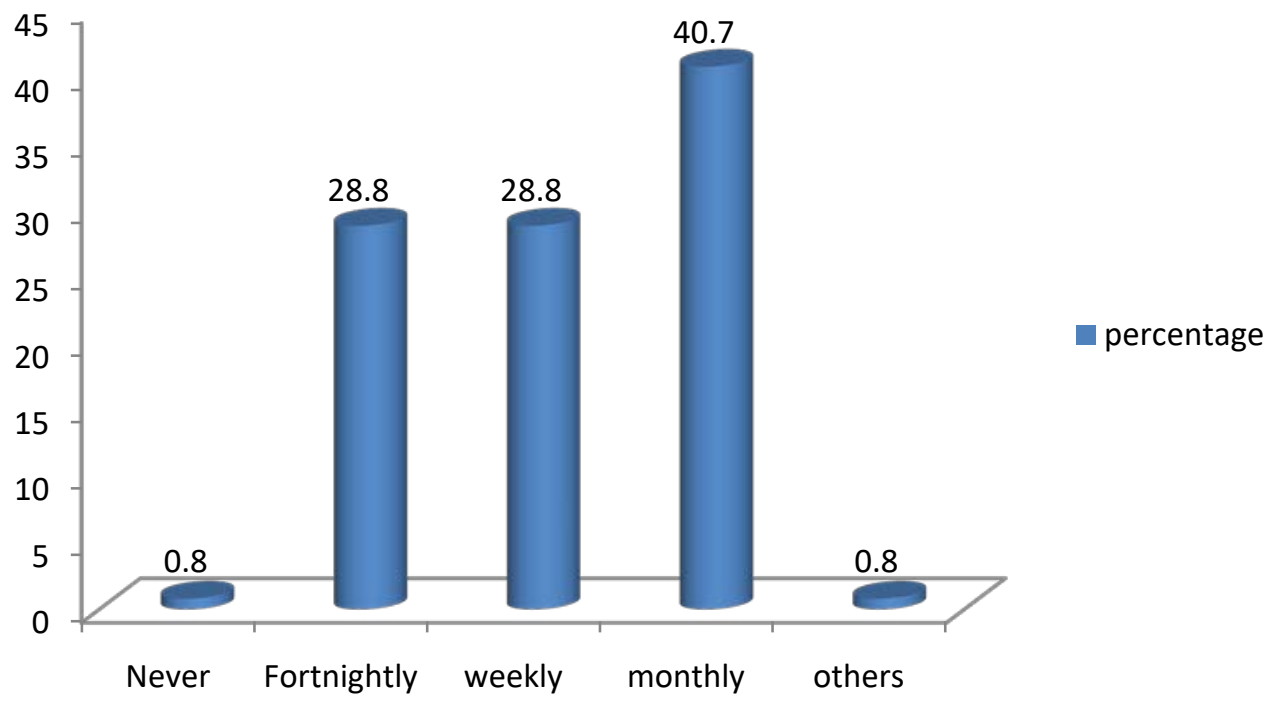

Figure 15. Time of Store Inspection.

Table 6 indicates that $82.9 \%$ add preservatives to their stored paddy rice, while $17.15 \%$ does not add preservatives. 
Table 6. Preservatives Application during Storage

\begin{tabular}{cccccc}
\hline & \multicolumn{4}{c}{ Preservatives used for paddy storage } \\
& Frequency & Percent & Valid Percent & Cumulative Percent \\
\hline \multirow{3}{*}{ Valid } & No & 21 & 17.1 & 17.1 & 17.1 \\
& Yes & 102 & 82.9 & 82.9 & 100.0 \\
& Total & 123 & 100.0 & 100.0 & \\
\hline
\end{tabular}

Figure 16 indicates that $56 \%$ among those respondent that add preservatives to their stored paddy rice used synthetic chemicals and $15 \%$ uses bio-pesticides as preservatives. This is in support of the statement by Obeng-Ofori [17] that the most important and effective curative measure in stored-product pest control is the application of synthetic residual or contact insecticides and their use will continue to be a major component of stored-product pest management strategies in Africa. While there are a wide variety of insecticidal products against field pests, there are only a few products available which meet the special requirements of pest control during storage.

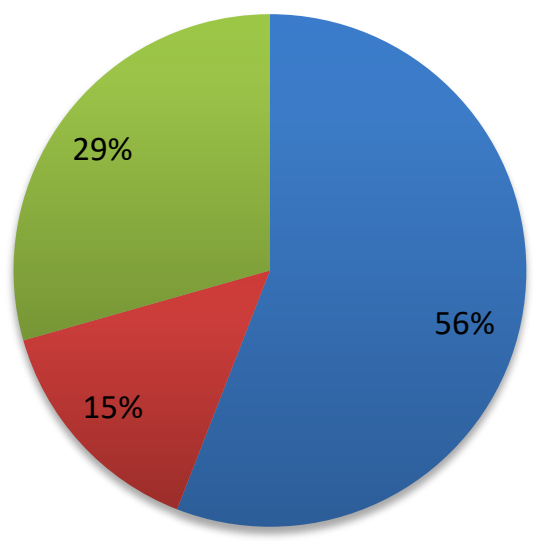

\author{
synthetic chemical \\ bio-pesticides \\ local methods
}

Figure 16. Types of preservatives used during storage.

It was observed from the report that youth are now engaged in rice farming, however, low awareness about the storage facilities affect the storage of rice for a long period of time. Therefore, more awareness is needed to improve postharvest handling and storage facilities of rice.

\title{
References
}

[1] Abo, M. E., Gana, A. S., Maji, A. T., Ojehomon, V. E. T., Ukwungwu, M. N., and Ochigbo, A. A. (2003). The challenges of rice varietal development and production in lowland ecology in Nigeria. Journal of Agricultural \& Food Information, 5(1), 51-66.

[2] Obi, G., Adama, M., Odukale, T., Emezie-Ezigbo, I., Funsho, A., and Onaiwu, E. (2019). Rice Industry Review. Home. kpmg/ng. 1-37.

[3] Iwuagwu, C. C., Umechuruba, C. I., Ononuju, C. C., and Nwogbqa, A. C. (2018). Assessment of Seed-Borne Plant Pathogenic Fungi associated with Rice Crop in South-Eastern Nigeria. Journal of Agricultural, Science and Technology, A(8), 68-75.

[4] Japan International Cooperation Agency. (2105). Handbook on Rice Postharvest Techniques. Pp. 1-26.

[5] FAO. (2014). Definitional framework of food loss. Working Paper. Rome.

[6] Afolami, C. A., Obayelu, A. E., Agbonhalor, M. U., and Lawal-Adebowale, O. A. (2012). Socioeconomic Analysis of Rice Farmers and effect of group formation on rice production in Ekiti and Ogun State of South-West Nigeria. Journal of Agricultural Science, 4(2), 233-244.

[7] Abdulhamid, A. T. and Solagberun, A. R. (2017). Perceived Effectiveness of Agricultural Extension Methods Used to Disseminate Improved Technologies to Rice Farmers in Kogi State, Nigeria. International Journal of Agricultural Science, Research and Technology in Extension and Education Systems (IJASRT in EESs), 7(1), 27-34. 
[8] Matanmi, B. M. Adesiji, G. B., Owawusi, W. O., and Oladipo, F. O. (2011). Perceived Factors Limiting Rice Production in Patigi Local Government Area of Kwara State, Nigeria. Journal of Agriculture and Social Research, 11(2), 40-45.

[9] Amponsah, S. K., Addo, A., Dzisi, K., Asante, B., and Afona, D. (2018). Assessment of rice farmer's knowledge and perception of harvest and postharvest losses in Ghana. Cogent Food and Agriculture, 4(1), 1471782.

[10] Ayanwale, A. B. and Amusan, C. A. (2014). Gender Analysis of rice production efficiency in Osun State: Implication for the Transformation Agenda. Nigeria Journal of Agricultural Economics, 4(1), 12-24.

[11] Ben-Chendo, G. N., Lawal, I. N, Ehirim, N. C., Nwaiwu, U. O., Onyemauwa. C. S., and Henri-Ukoha, A. (2016). Profitability and risk management techniques of paddy production in Kaduna state, Nigeria. Sky Journal of Agricultural Research, 5(1), 022-028.

[12] Erenstein, O., Lancon, F., Akande, S. O.,Titilola, S. O., Akpokodie, G., and Ogundele, O. O. (2003). Rice Production Systems in Nigeria, A Survey, The Nigeria Rice Economy in a Competitive World: Constraints, Opportunities and Strategic Choices. WARDA, Abidjan, Cote d"Ivoire. 1-95.

[13] Adejumo, B. A. and Raji, A. O. (2007). Technical Appraisal of Grain Storage Systems in the Nigerian Sudan Savanna. Agricultural Engineering International: the CIGR Ejournal. Invited Overview, 7(11), 1-12.

[14] Ashok, Gowd, B. and Shakunthala, N. M. (2018). Different Types of Grain Storage Structures for the Betterment of Livelihood of Indian Farmers. International. Journal Pure and Applied Bioscience, 6(4), 190-198.

[15] Orifah, M. O., Sani, M. H., Muritala, N., and Ibrahim, A. A. (2020). Analysis of Rice Farmers Awareness of the effects of climate change in Kebbi State, NorthWest, Nigeria. FUDMA Journal of Agriculture and Agricultural Technologies, 6(1).

[16] Scott, J. (2018). Eight Tips for Long-Term Grain Storage. Successful Farming.

[17] Obeng-Ofori, D., Adarkwa, C. and Ulrich, C. (2015). Chemical, physical and organic hermetic storage technology for stored-product protection in African countries. Integrated Protection of Stored Products IOBC-WPRS Bulletin, $111,3-27$. 